\title{
Efektivitas Teh Bawang Dayak untuk Menurunkan Kadar Gula Darah Pasien Diabetes Mellitus Tipe 2
}

\author{
Annaas Budi Setyawan ${ }^{1}$, Rusni Masnina ${ }^{1}$ \\ ${ }^{1}$ Program Studi Keperawatan Universitas Muhammadiyah Kalimantan Timur \\ Email: abs564@umkt.ac.id
}

Received 13 August 2018; Accepted 15 August 2018; Published 6 November 2018

\begin{abstract}
ABSTRAK
Pasien Diabetes Mellitus tipe 2 mengalami dua masalah utama yang berhubungan dengan insulin, yaitu penurunan sensitivitas terhadap insulin (resistensi insulin) dan gangguan sekresi insulin. Hal ini sering terjadi pada seseorang dengan diabetes yang berusia lebih dari 30 tahun dan obesitas. Hal tersebut menyebabkan peningkatan glukosa darah dan juga komplikasi lain seperti peningkatan kolesterol jahat dalam darah. Pengetahuan tentang khasiat dan keamanan tanaman obat di Indonesia biasanya hanya berdasarkan pengalaman empiris yang biasanya diwariskan secara turun temurun dan belum teruji secara ilmiah. Untuk itu diperlukan penelitian tentang obat tradisional, sehingga nantinya obat tersebut dapat digunakan dengan aman dan efektif. Rancangan penelitian dengan quasi ekperimental, Besaran sampel 20 orang, kelompok intervensi 10 orang, kelompok kontrol 10. Kelompok intervensi mendapatkan teh bawang dayak yang diminumkan sekali sehari pada pagi hari selama 2 minggu. Analisa data untuk mengetahui perbedaan kelompok kontrol dan intervensi menggunakan uji mann whitney. Hasil Penelitian didapatkan uji mann whitney dengan $p$ value 0,004 $(<0,05)$ yang berarti ada perbedaan bermakna kadar glukosa pada pasien diabetes mellitus yang diberikan teh bawang dayak dengan yang tidak diberikan.
\end{abstract}

Kata kunci : Teh bawang dayak, gula darah, diabetes mellitus Tipe 2

Copyright $@ 2018$ STIKes Surya Mitra Husada

All right reserved.

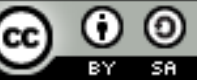

This is an open-acces article distributed under the terms of the Creative Commons AttributionShareAlike 4.0 International License.

\section{PENDAHULUAN}

Pasien Diabetes Mellitus tipe 2 mengalami dua masalah utama yang berhubungan dengan insulin, yaitu penurunan sensitivitas terhadap insulin (resistensi insulin) dan gangguan sekresi insulin. Hal ini sering terjadi pada seseorang dengan diabetes yang berusia lebih dari 30 tahun dan obesitas (Price \& Wilson, 2010).

WHO memprediksi kenaikan jumlah penyandang DM di Indonesia dari 8,4 juta pada tahun 2000 menjadi sekitar 21,3 juta pada tahun 2030. Laporan ini menunjukkan adanya peningkatan jumlah penyandang DM sebanyak 2-3 kali lipat pada tahun 2035. Sedangkan International Diabetes Federation (IDF) memprediksi adanya kenaikan jumlah penyandang DM di Indonesia dari 9,1 juta pada tahun 2014 menjadi 14,1 juta pada tahun 2035 (PERKENI, 2016).

Data menurut profil kesehatan provinsi Kalimantan Timur tahun 2016, menyatakan bahwa Diabetes mellitus masuk kedalam 10 besar penyakit morbiditas yang ada di Puskesmas. Morbiditas adalah angka kesakitan, dapat berupa angka insidensi maupun angka prevalensi dari suatu penyakit. 
Morbiditas menggambarkan kejadian penyakit dalam suatu populasi dan pada kurun waktu tertentu. Morbiditas berperan dalam penilaian terhadap derajat kesehatan masyarakat di suatu wilayah (Dinkes Prov Kaltim, 2016).

Jumlah pasien DM yang melakukan kunjungan Puskesmas di wilayah Samarinda pada tahun 2014 tercatat sebanyak 8.997 kunjungan. Kunjungan Puskesmas untuk DM tipe 1 sebanyak 2.964 kunjungan dan DM tipe 2 sebanyak 6.033 kunjungan (Dinas Kesehatan Kota Samarinda, 2015). Tahun 2015 terjadi peningkatan jumlah kunjungan pasien DM yaitu sebanyak 11.587 kunjungan, untuk DM tipe 1 sebanyak 4.204 kunjungan dan untuk kunjungan DM tipe 2 sebanyak 7.383 kunjungan (Dinas Kesehatan Kota Samarinda, 2016).

Bawang dayak (Eleutherine palmifolia) merupakan tanaman khas Kalimantan. Tanaman ini memiliki daun berwarna hijau dengan bunga berwarna putih serta umbi berwarna merah yang menyerupai bentuk umbi bawang merah. Air rebusan atau perasan umbi bawang dayak secara tradisional diyakini mempunyai berbagai khasiat, antara lain sebagai obat kanker payudara, darah tinggi (hipertensi), kencing manis (diabetes melitus), kolesterol, dan bisul (Galingging, 2007).

Pengetahuan tentang khasiat dan keamanan tanaman obat di Indonesia biasanya hanya berdasarkan pengalaman empiris yang biasanya diwariskan secara turun temurun dan belum teruji secara ilmiah. Untuk itu diperlukan penelitian tentang obat tradisional, sehingga nantinya obat tersebut dapat digunakan dengan aman dan efektif (Setyawan, 2018).

Aktivitas antioksidan dan inhibitor alfa glukosidase yang terdapat pada ekstrak etanol umbi bawang dayak lebih besar dibandingkan yang terdapat pada ekstrak air. Hasil penapisan fitokimia dan penghitungan total flavonoid dan total fenol juga memperlihatkan jenis dan kandungan senyawa fitokimia yang lebih besar pada ekstrak etanol dibandingkan pada ekstrak air. Perpaduan kapasitas antioksidan dan kemampuan peng- hambatan enzim alfa glukosidase yang terdapat pada umbi bawang dayak menunjukkan bahwa umbi bawang dayak memiliki potensi sebagai agen antidiabetik yang bermanfaat dalam pencegahan dan perlindungan (prophylaxis) terhadap penyakit diabetes mellitus (Febrinda, et al , 2013).

Menurut studi pendahuluan yang sudah dilakukan dari 10 pasien DM tipe 2 yang diwawancarai 6 orang sudah mengetahui tentang manfaat teh bawang dayak dan sudah pernah membuatnya, namun 4 orang lainnya belum mengetahui manfaat bawang dayak. Tujuan penelitian ini untuk membuktikan efek teh bawang dayak terhadap penurunan kadar glukosa pasien diabetes mellitus tipe 2

\section{BAHAN DAN METODE}

Jenis penelitian ini merupakan penelitian kuantitatif dengan menggunakan desain penelitian eksperimen semu (quasy-experiment) dengan pendekatan pretest-posttest control group design. Besar sampel yang digunakan sebanyak 20 orang yang dibagi dalam 2 kelompok, 10 orang kelompok kontrol dan 10 orang kelompok perlakuan.

Pada kelompok intervensi teh bawang dayak diberikan selama 2 minggu dengan pemberian sehari sekali pada pagi hari. Sedangkan pada kelompok kontrol diberi minuman berupa seduhan daun teh tanpa gula. Kriteria inklusi dalam penelitian ini yaitu: responden yang tinggal di wilayah kerja Puskesmas Juanda Samarinda, responden yang mengikuti intervensi dari awal sampai akhir, berusia 30 sampai 65 tahun, responden dengan diabetes mellitus tipe 2 dengan kada gula darah 200-400mg/dl. Kriteria eksklusi dalam penelitian ini yaitu: responden DM yang mendapatkan terapi suntik insulin dan obat oral antidiabetik serta memiliki komplikasi penyakit berat seperti gagal ginjal penyakit jantung. Pemberian teh bawang dayak sebanyak 3 sendok teh yang dimasukan dalam $75 \mathrm{~mL}$ air hangat (gelas duralex) hingga warna berubah menjadi kemerahan (Nirmala, 2010). Pengukuran gula darah menggunakan alat pengukur glukosa digital yang sudah dikalibrasi.

Penelitian ini dilakukan di wilayah kerja Puskesmas Juanda Samarinda. Pemilihan lokasi penelitian berdasarkan pertimbangan dari data klien DM yang mengalami peningkatan kunjungan sebanyak 2 kali lipat sejak tahun 2014 hingga tahun 2016, selain itu Puskesmas Juanda menduduki 10 besar dengan jumlah kunjungan klien terbanyak di wilayah kota Samarinda.

Analisa bivariat pada penelitian ini menggunakan uji mann whitney untuk mengetahuai perbedaan antara kelompok kontrol dengan kelompok intervensi. Penelitian ini telah mendapatkan persetujuan dari komisi etik penelitian kesehatan Politeknik Kesehatan Kalimantan Timur dengan 
Keterangan Kelaikan Etik (Ethical Clearence) Nomor: LB. 02.01/7.1/5071/ 2018.

\section{HASIL}

1. Karakteristik Responden

Tabel 1. Distribusi Karakteristik Responden Berdasarkan Umur, Jenis Kelamin Dan Status Merokok Di Wilayah Kerja Puskesmas Juanda Samarinda Juni-Juli 2018

\begin{tabular}{|c|c|c|}
\hline Karakteristik & Frekuensi & Persentase \\
\hline \multicolumn{3}{|l|}{ 1. Umur } \\
\hline 40-54 tahun & 7 & 35,0 \\
\hline 55-64 tahun & 10 & 50,0 \\
\hline$>65$ tahun & 3 & 15,0 \\
\hline \multicolumn{3}{|l|}{ 2. Jenis Kelamin } \\
\hline Laki-Laki & 4 & 20,0 \\
\hline Perempuan & 16 & 80,0 \\
\hline \multicolumn{3}{|l|}{ 3. Status Merokok } \\
\hline Merokok & 3 & 15,0 \\
\hline Tidak Merokok & 17 & 85,0 \\
\hline Total & 20 & 100 \\
\hline
\end{tabular}

Sumber: Data Primer 2018

Hasil analisis distribusi karakteristik responden pada tabel 1 berdasarkan umur diketahui sebagian besar berusia 55-64 tahun sebanyak 10 orang (50,0\%), kemudian berdasarkan jenis kelamin sebagian besar adalah perempuan sebanyak 16 orang $(80,0 \%)$ dan data mengenai status merokok diketahui sebagian besar tidak merokok sebanyak 17 orang $(85,0 \%)$.

2. Perubahan Rata-Rata Kadar Gula Darah Sebelum dan Sesudah Pada Kelompok Kontrol dan Intervensi

Tabel 2 Hasil Perbedaan Kadar Gula Darah Sebelum Dan Sesudah Pada Kelompok Kontrol Dan Intervensi

\begin{tabular}{ccccc}
\hline Kelompok & $(\mathrm{Mean} \pm \mathrm{SD})$ & $95 \% \mathrm{CI}$ & $\mathrm{t}$ & $\mathrm{p}$ \\
\hline Intervensi & $51.60 \pm 35.90$ & $20.18 ; 28.41$ & 13.35 & 0.001 \\
Kontrol & $24.30 \pm 5.755$ & $25.19 ; 77.28$ & 4.54 & 0.001 \\
\hline
\end{tabular}

Sumber data primer 2018

Tabel 2 menunjukkan bahwa berdasarkan uji Paired t-test terdapat perbedaan kadar gula darah yang bermakna antara sebelum dan sesudah pada kelompok intervensi dengan nilai 0,001 lebih kecil dari taraf signifikansi 95\% $(\mathrm{p}<0,05)$ dengan nilai interval kepercayaan 20.18-28.41. Pada kelompok intervensi terjadi penurunan kadar gula darah ditandai dengan nilai t hitung $(\mathrm{t}=13.35)$, sedangkan pada kelompok kontrol terjadi penurunan kadar gila darah dengan nilai $t$ hitung $(t=4.54)$. 
3. Perbedaan Perubahan Kadar Glukosa Kelompok Intervensi dan Kontrol

Tabel 2 Hasil Perbedaan Perubahan Kadar Glukosa Kelompok Intervensi dan Kelompok Kontrol

\begin{tabular}{lccccc}
\hline Responden & Jumlah & Variabel & Mean & Z & $\mathrm{P}^{*}$ \\
\hline Intervensi & 10 & Kadar Glukosa & 6.65 & -2.913 & 0,004 \\
Kontrol & 10 & & 14.35 & & \\
\hline
\end{tabular}

Sumber data primer 2018

Tabel 2 menunjukan terdapat perbedaan perubahan kadar glukosa setelah intervensi yang bermakna antara kelompok intervensi dan kelompok kontrol dengan hasil melalui uji Mann Withney test diperoleh angka signifikansi $0,004(\mathrm{p}<0,05)$ yang berarti ada perbedaan bermakna kadar glukosa pada pasien diabetes mellitus yang diberikan teh bawang dayak dengan yang tidak diberikan. Kemudian rata-rata kadar gula darah kelompok intervensi 6.65 sedangkan kelompok kontrol 14.35. Pada mann whitney yang dijadikan perbandingan adalah setelah perlakuan baik itu kelompok kontrol dan intervensi, sehingga terlihat rata-rata kelompok intervensi lebih rendah karena mengalami penurunan lebih banyak dibanding pada kelompok kontrol (Dahlan, 2014).

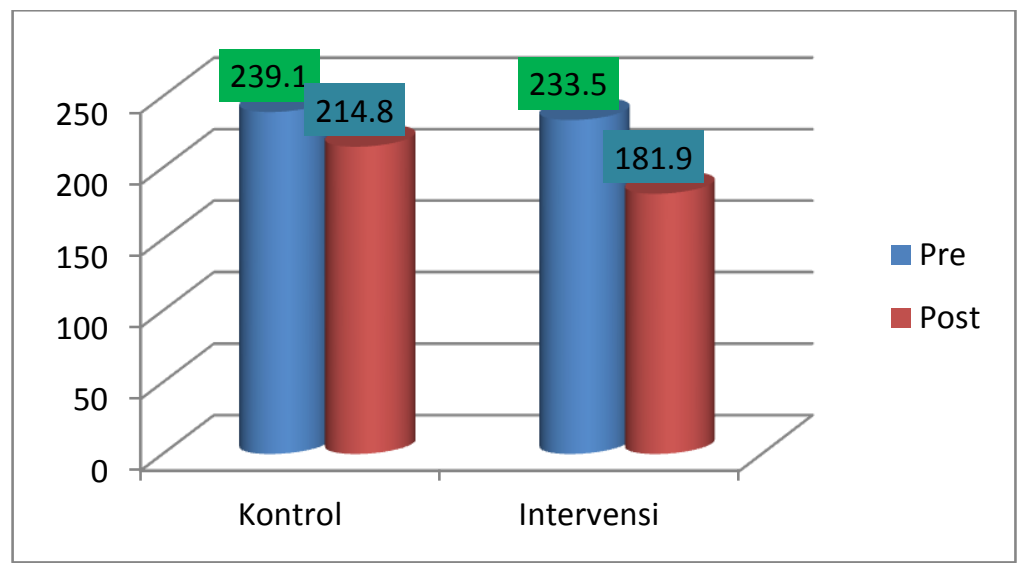

Gambar 1 Perbedaan kadar gula darah sebelum dan sesudah pada kelompok kontrol dan intervensi

\section{PEMBAHASAN}

Hasil penelitian pada tabel 1 menunjukkan bahwa terbanyak responden berada pada usia 5564 tahun yaitu sebanyak 10 orang (50\%). Resiko terjadinya penyakit DM tipe 2 meningkat dengan bertambahnya usia, terutama usia diatas 40 tahun. Menurut Nugroho (2000 dalam Efendi dan Makhfudi 2009) semua pasien DM tipe 2 termasuk dalam kelompok usia yang sama yaitu $40-65$ tahun yang merupakan masa setengah umur.

Faktor usia berpengaruh terhadap kondisi kesehatan seseorang, hal ini terjadi karena semakin tua kemampuan mekanisme kerja bagian-bagian organ tubuh seseorang akan mengalami penurunan seperti absorbsi, sintesis dan ekskresi lemak akan mulai berkurang. Termasuk juga penurunan fungsi kelenjar pankreas dalam menghasilkan insulin yang dapat menyebabkan glukosa tidak dapat masuk ke dalam sel dan kembali kedalam darah sehingga terjadi hiperglikemi pada pasien diabetes mellitus (Efendi dan Makhfudi 2009). Hasil penelitian ini mendukung teori bahwa seiring dengan bertambahnya usia, manusia mengalami penurunan fisiologis yang menurun dengan cepat setelah usia 40 tahun, dimana hal ini merupakan salah satu faktor terjadinya DM tipe 2. Penurunan fisiologis yang terjadi mempengaruhi penurunan fungsi endokrin pankreas untuk memproduksi insulin.

Jenis kelamin responden dalam penelitian ini sebagian besar adalah perempuan dengan jumlah 16 orang $(80,0 \%)$. Hasil penelitian ini sesuai dengan teori yang menyatakan bahwa penyakit DM tipe 2 lebih sering terjadi pada perempuan yang sudah monopuse. Setelah menopause, perubahan tingkat hormon tubuh dapat memicu fluktuasi dalam kadar gula darah. Hal ini menyebabkan kadar 
gula darah lebih sulit diprediksi dibandingkan pada masa sebelum menopause. Jika kadar gula darah tidak terkontrol, maka akan memiliki risiko komplikasi diabetes yang lebih tinggin (Nilawati, 2008). Selain itu kehilangan hormone progesterone membuat terjadinya peningkatan kadar lipid (lemak darah) pada perempuan lebih tinggi dibandingkan pada laki-laki, jumlah lemak pada laki-laki dewasa rata-rata berkisar antara $15-20 \%$ dan berat badan total, dan pada perempuan sekitar $20-25 \%$ sehingga faktor risiko terjadinya DM pada perempuan $3-7$ kali lebih tinggi dibandingkan pada lakilaki yaitu $2-3$ kali (Nurlaily, 2010).

Hasil penelitian pada tabel 1 menunjukkan sebagian besar responden tidak merokok sebanyak 18 orang $(85,0 \%)$. Menurut teori, kebiasaan merokok dapat menyebabkan terjadinya diabetes mellitus karena terjadinya resistensi insulin yang membuat glukosa tidak dapat diubah menjadi energi pada tingkat sel (Nilawati, 2008). Penelitian yang dilakukan oleh American Diabetes Association (ADA) (Nilawati, 2008) menunjukkan merokok 20 batang atau lebih per hari mengakibatkan terjadinya peningkatan glukosa sekitar $11 \%$ untuk lakilaki dan $14 \%$ untuk perempuan. Merokok dapat menyebabkan terjadinya hiperglikemi pada pasien diabetes mellitus.

Hasil penelitian didapatkan bahwa seluruh responden tidak ada yang merokok, dengan tidak adanya responden yang merokok dalam penelitian ini maka salah satu faktor yang dapat memperburuk kondisi klien DM tipe 2 dapat dihindari, karena dengan merokok dapat meningkatkan kadar LDL dan menurunkan kadar HDL. Kadar kolesterol yang tidak dikontrol dengan baik dalam jangka waktu tertentu akan menyebabkan terjadinya komplikasi-komplikasi yang lebih serius pada klien DM tipe 2.

Hasil analisa dengan uji mann whitney menunjukan terdapat perbedaan rata-rata kadar glukosa setelah intervensi yang bermakna antara kelompok intervensi dan kelompok kontrol dengan hasil melalui uji Mann Withney test diperoleh angka signifikansi $0,004(\mathrm{p}<0,05)$ yang berarti ada perbedaan bermakna kadar glukosa pada pasien diabetes mellitus yang diberikan teh bawang dayak dan tidak. Kemudian terjadi perbedaan rata-rata kadar gula darah kelompok kontrol 14,35, sedangkan kelompok intervensi 6,65 yang berarti terjadi perbedaan penurunan rata-rata kadar gula darah kelompok kontrol dan intervensi.

Hasil penelitian ini sesuai dengan penelitian Febrinda, dkk (2013) bahwa umbi bawang dayak merupakan agen antidiabetik yang bermanfaat dalam pencegahan dan perlindungan terhadap penyakit diabetes mellitus dengan cara bekerja sebagai penghambat alfaglukosidase.

Umbi bawang dayak mengandung alkaloid, flavonoid, saponin, terpenoid, steroid, glikosida, tanin, fenolik, antrakuinon. Golongan senyawa kimia yang terdapat pada ekstrak etanol umbi bawang dayak adalah alkaloid, flavonoid, glikosida, saponin, antrakuinon glikosida, tanin dan triterpenoid/steroid. Golongan senyawa kimia yang terdapat pada fraksi etilasetat adalah senyawa fenol, tanin dan flavonoid (Subramaniam, et al., 2012)

Inhibitor alfa glukosidase (alpha glucosidase inhibitor, AGI) merupakan salah satu agen antidiabetik yang bekerja dengan cara menghambat kerja enzim alfa glukosidase. Pengurangan penyerapan karbohidrat dari makanan oleh usus merupakan sebuah pendekatan terapeutik bagi hiperglikemia postpandrial. Polisakarida kompleks akan dihidrolisis oleh enzim amilase menjadi dekstrin dan dihidrolisis lebih lenjut menjadi glukosa oleh enzim alpha glukosidase sebelum memasuki sirlulasi darah melalui penyerapan epitelium. Amilase dan alpha glukosidase inhibitor sintetis, seperti misalnya acarbose, telah banyak digunakan untuk penanganan pasien diabetes tipe II namun obat ini juga dilaporkan menyebabkan berbagai efek samping (Feng et al. 2011). Sehubungan dengan hal tersebut banyak usaha yang telah dilakukan untuk menemukan AGI dari sumber alami untuk mengobati diabetes.

Aktivitas glukosidase merupakan hal yang fundamental bagi beberapa proses biokimia seperti degradasi polisakarida menjadi unit mono-sakarida, agar dapat diserap dan digunakan oleh organism. Oleh karena itu pada kondisi hiperglikemia dimana konsentrasi gula pada darah tinggi melebihi normal seperti yang terjadi pada penderita diabetes, penghambatan kerja enzim alfa glukosidase dapat membantu mengatasi kondisi hiperglikemia karena jumlah monosakarida yang dapat diserap oleh usus menjadi berkurang. 


\section{SIMPULAN DAN SARAN}

\section{Kesimpulan}

Teh bawang dayak terbukti mampu menurunkan kadar gula darah pada pasien diabetes mellitus tipe 2, hal itu terlihat dari rata-rata pada kelompok intervensi (6.65) lebih kecil dibanding rata-rata kelompok kontrol (14.35). Hal itu terjadi karena pada kelompok intervensi terjadi penurunan kadar gula darah lebih banyak dibandingkan kelompok kontrol. Selain itu didapatkan p value 0,004 $(<0,05)$ yang berarti ada perbedaan bermakna kadar glukosa pada pasien diabetes mellitus yang diberikan teh bawang dayak dengan yang tidak diberikan.

\section{Saran}

Teh bawang dayak bisa digunakan sebagai upaya non farmakologi dalam menurunkan kadar gula darah pasien diabetes mellitus tipe 2 .

\section{UCAPAN TERIMA KASIH}

Penulis mengucapkan terima kasih kepada Direktorat Riset dan dan Pengabdian Masyarakat Kementerian Riset, Teknologi dan Pendidikan Tinggi atas hibah penelitian skema penelitian dosen pemula dengan kontrak penelitian Tahun Anggaran 2018 dengan kontrak penelitian nomor 115/Sp2H/LT/DRPM/2017.

\section{DAFTAR PUSTAKA}

Setyawan, A. B. (2018). Efektivitas Senam Diabetes Melitus Untuk Menurunkan Kadar Kolesterol Pasien Diabetes Melitus. Husada Mahakam 1 (I), 98-107.

Dinas Kesehatan Kota Samarinda. (2016). Laporan Kunjungan (LBI) DM Kota Samarinda Tahun 2015. Samarinda: Dinas Kesehatan Kota Samarinda.

Dinas Kesehatan Provinsi Kalimantan Timur. (2016). Profil Kesehatan Provinsi Kalimantan Timur 2016. Samarinda: Dinas Kesehatan KalimantanTimur.

Effendi, F. \& Makhfudli. (2009). Keperawatan Kesehatan Komunitas: Teori dan Praktek Dalam Keperawatan. Jakarta: Salemba Medika.

Febrinda, E. A., Astawan, M., Wresdiyati, T., \& Dewi Yuliana, N. (2013). Kapasitas Antioksidan Dan Inhibitor Alfa Glukosidase Ekstrak Umbi Bawang Dayak. Jurnal Teknologi Dan Industri Pangan, 24(2), $161-167$. https://doi.org/10.6066/jtip.2013.24.2.161.

Feng, J., Yang, X. W., Wang, R. F. (2011). Bio-assay guided isolation and identification of a-glucosidase inhibitors from the leaves of Aquilaria sinensis. Phytochemistry 72: 242-247. DOI: 10.1016/j.phytochem.2010.11.025.

Galingging, R. Y. (2007). Potensi plasma nutfah tanaman obat sebagai sumber biofarmaka di Kalimantan Tengah. J Pengkajian dan Pengembangan Teknologi Pertanian 10: 76-83.

Nirmala, R. (2010). Budidaya Pengembangan Bawang Tiwai/Bawang Dayak (Eleutherine americana (L). Merr.). Erlangga. Jakarta.

Nurlaily. (2010). Analisis Beberapa Faktor Risiko Terjadinya Diabetes Mellitus pada RSUD dr. Mm. Dunda Limboto Kab. Gorontalo. [serial online].

http://dc162.4shared.com/doc/nQxQGwrK/preview.html. [08 Agustus 2018].

Nilawati. (2008). Care Yourself Kolesterol. Cetakan 1. Jakarta: Penebar Plus. 
Price, Sylvia, \& Lorraine, W. (2010). Patofisiologi: Konsep Klinis Proses-Proses Penyakit. Edisi 8. Jakarta: EGC.

Perkumpulan Endokrinologi Indonesia (PERKENI). (2016). Konsensus Pengelolaan dan Pencegahan Diabetes Mellitus Tipe 2 di Indonesia. Jakarta: PERKENI.

Subramaniam, K., Sembian, S., Femina, W., Febrina, B. S. \& Gilbert, R. R. (2012). Antagonistic Activity of Eleutherine palmifolia Linn. Asian Pacific Journal of Tropical Disease. S491-493.

World Health Organization. (2012). Prevalence of Diabetes in the WHO South-East Asia Region. [serial online]. http://www.who.int/diabetes/facts/world_figures/en/. 